Original Paper

\title{
Pengembangan Potensi Objek Wisata Alam Berbasis Konservasi di Desa Pijot Induk Kecamatan Keruak Lombok Timur
}

\author{
Abdul Syukur ${ }^{1 *}$, Karnan$^{1}$, Khairuddin', M. Yamin ${ }^{1}$ \\ ${ }^{1}$ Program Studi Pendidikan Biologi, Fakultas Keguruan dan Ilmu Pendidikan, Universitas Mataram, Indonesia
}

DOI: $10.29303 /$ jpmpi.v2i2.369

Sitasi: Cholidah, R., Widiastuti, I. A. E., Lestarini, I. A. (2019). Pengembangan Potensi Objek Wisata Alam Berbasis Konservasi di Desa Pijot Induk Kecamatan Keruak Lombok Timur. Jurnal Pengabdian Magister Pendidikan IPA (JPMPI). (2) 2. pp. 118-121

*Corresponding Author: Abdul Syukur, Program Studi Pendidikan Biologi, Fakultas Keguruan dan Ilmu Pendidikan, Universitas Mataram, Indonesia;

Email:

syukubiologi@unram.ac,id

\begin{abstract}
Abstrak: Desa Pijot adalah desa pantai yang memiliki potensi wisata alam di Kecamatan Keruak Lombok Timur. Potensi wisata alam di Desa Pijot adalah: (1) wisata pantai, (2) wisata mangrove dan (3) wisata pemandian Kebon Telage. Namun demikian potensi yang besar tersebut belum dikembangkan secara optimal untuk berkontribusi sebagai sumber ekonomi masyarakat masyarakat lokal. Tujuan program pengabdian ini adalah: (1) masyarakat desa pijot memiliki kelembagaan pengeloaan ekowisata, (2) ekowisata menjadi sumber baru matapencahraian masyarakat dan (3) program pengembangan ekowisata berbasis konservasi. Hasil.
\end{abstract}

Kata Kunci: Ekowisata; Objek Wisata; Konservasi

\section{Pendahuluan}

Desa Pijot secara administartif adalah wilayah dari Kecamatan Keruak Kabupaten Lombok Timur, dengan batas sebelah utara Desa Pijot Utata, sebelah selatan Desa Tanjung Luar dan Desa Ketapang Raya, sebelah timur Desa Menceh dan sebelah barat Desa Ketangga Jeraeng dan Desa Montong Belai (KKN, 2017). Desa Pijot adalah salah satu desa pantai dengan jumlah penduduk 6113 jiwa. Pendidikan masyarakat di Desa Pijot adalah: (1) usia 7 - 18 tahun yang tidak sekolah 15orang, (2) usia 18-56 tahun tidak pernah sekolah 97 orang laki - laki dan dan 102 orang perempuan (3) Usia 18-56 thn sudah mengeyam pendidikan SD tetapi tetapi tidak selesai 185 orang laki- laki dan 284 orang perempuan, (4) tamat SD/sederajat 767 orang laki-laki dan 545 orang perempuan, (5) usia 12 - 56 tahun tidak tamat SLTP sebanyak 105 orang laki - laki dan 121 orang perempuan, (6) usia 18 - 56 tahun tidak tamat SLTA 37 orang laki - laki dan 22 orang perempuan, (7) usia 18 - 56 tamat SMP/sederajat 311 orang laki - laki dan 367 orang perempuan, (8) SMA/sederajat 177 orang laki - laki dan 161 orang perempuan, (9) D2/sederajat 7 orang laki - laki dan 2 orang perempuan, (10) D-3/sederajat 1 orang laki - laki,
(10) S-1/sederajat 28 orang laki - laki dan 11 orang perempuan dan (11) S-2/sederajat 2 orang laki laki (Monografi Desa Pijot 2017).

Penduduk Desa Pijot yang berprofesi sebagai peternak sebanyak 1037 orang, buruh tani sebanyak 670 orang dan nelayan kecil 474 orang. Selanjutnya jumlah keluarga yang memiliki lahan pertanian sebanyak 915 keluarga dan yang memiliki tanah perkebunan sebanyak 1112 keluarga dengan luas lahan perkebunan 197 ha, persawahan 149 ha. Komoditas utama di bidang perkebunan adalah berupa kelapa dan tembakau. Komoditas utama pada sektor peternakan adalah ayam kampung, sapi 235 ekor, kuda 15 ekor dan kerbau 13 ekor (KKN, 2018). Kondisi alam Desa Pijot yang masih alami dan mudah diakses memiliki peluang untuk dikembangkan sebagai objek wisata. Pengembangan objek wisata di Desa Pijot memiliki makna yang strategis untuk membuka lapangan kerja bagi masyarakat, seperti yang telah dikembangkan pada desa tetangga dari Desa Pijot yaitu Desa Ketapang Raya.

Desa Pijot sebagai desa pantai memiliki potensi wisata alam sebagai salah satu keunggulannya. Adapun potonsi wisata alam di Desa Pijot adalah: 
1) Pantai, panjang pantai Desa Pijot Induk $\pm 3 \mathrm{~km}$ terletak di sebelah selatan dan Timur yang berhadapan langsung dengan Selat Alas. Pantai di Desa Pijot Induk mudah diakses melalui jalan utama Keruak - Labuan Haji dan dari Kota Kabupaen Selang jaraknya $\pm 20 \mathrm{~km}$. Selanjutnya, jarak dari pusat Kota Mataram ke Pantai Batu Selayar $61 \mathrm{~km}$ yang bisa ditempuh dalam waktu 1 jam 30 menit. Obyek wisata pantai yang menarik dikunjungi wisatawan di Desa Pijot adalah Pantai Batu Selayar pada bagian timur yang berhadapan langsung dengan Selat Alas dan tipe pantainya pada (Gambar 1).

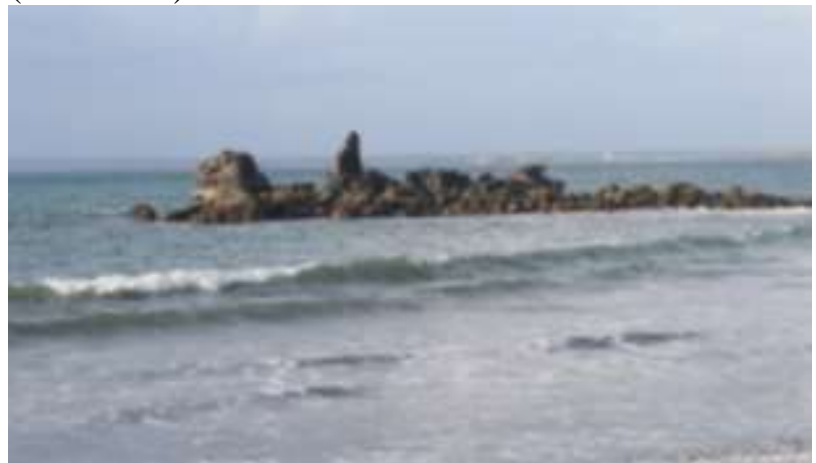

Gambar 1. Pantai Batu Selayar di Desa Pijot (KKN, 2018)

Potensi lain pada objek wisata pntai Selayar adalah keberadaan padang savana sebagai objek wisata (Gambar 2). Hamparan padang savanna membentang dari ujung timur hingga ujung selatan pantai batu selayar.

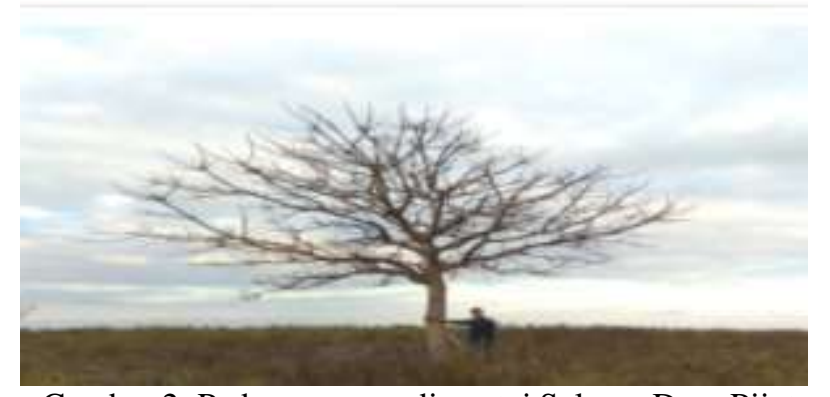

Gambar 2. Padang savana di pantai Selayar Desa Pijot (KKN, 2018)

2) Hutan bakau atau disebut juga hutan mangrove adalah hutan yang tumbuh di air payau, dan dipengaruhi oleh pasang-surut air laut. Desa Pijot memiliki areal mangrove sebagai objek wisata dan pendidikan dan terletak pada dua lokasi yaitu di sebeah selatan dan di sebelah timur. Akses menuju lokasi mangrove cukup mudah karena letaknya tidak jauh dari jalan utama Keruak-Labuan Haji. Sejarah kembali hutan mangrove di Desa Pijot Induk, dimana pada tahun 1993 untuk menyambut kedatangan presiden Soeharto, dilakukan reboesasi. Hasilnya sampai saat ini mangrove telah tumbuh dengan subur (Gambar 3) dan banyak dimanfaatkan sebagai areal mencari ikan, kepiting, udang dan moluska oleh masyrakat sekitar.

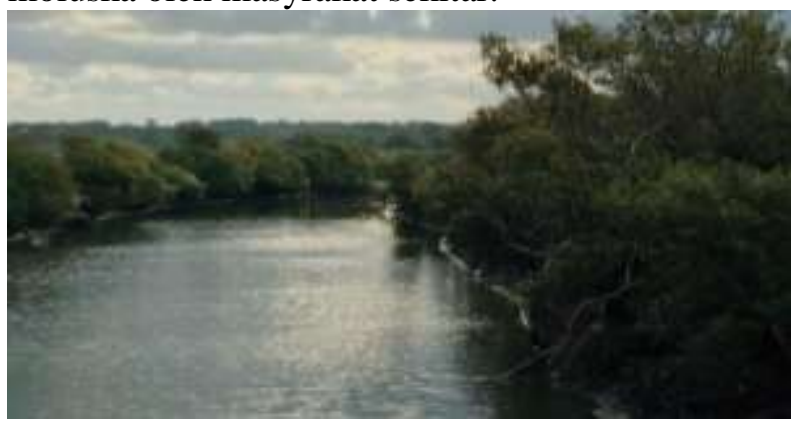

Gambar 3. Kondisi manrove di Desa Pijot (KKN, 2018)

3) Taman pemandian, Desa Pijot memiliki objek wisata kolam renang yang diberi nama Kebon Telage. Nama wsata permandian ini memiliki sejarah dari peninggalan tokoh agama yang menyebarkan agama islam di wilayah Selatan Lombok Timur. Kolam Telage Tibu Gempur merupakan kolam renang yang dirintis oleh pemerntah desa dan mahasiswa KKN Universitas Mataram periode Juli - September 2018. Luas areal yang direncanakan seluas 1 hektar. Saat ini masih dalam proses pembuatan kolam dan inprastruktur lainya. Objek wisata kolam renang di Desa Pijot adalah yang pertama di wilayah selatan Lombok Timur.

Potensi ekowisata di Desa Pijot, seperti yang telah disebutkan di atas adalah keunggulan komparatif yang dapat dikembangkan sebagai objeks wisata. Wisata alam di wilayah Selatan Lombok Timur adalah objkes wisata yang sudah mulai berkembang, seperti di Desa Ketapang Raya. Oleh karena itu, beberapa desa yang memiliki potensi telah merencanakan dalam pembagunan desa untuk mengembangkan ekowisata, seperti Desa Pijot. Potensi lain yang mendukung pengembangan ekowisata di Desa Pijot adalah infrastruktur jalan.

\section{Bahan dan Metode}

\section{A. Persiapan}

Program pengabdian yang telah dilakukan oleh Tim, melalui tahapan persiapan yang meliputi: 1. materi manajemen ekowisata yang melipti materi: (a) peningkatan kapasiatas pengetahuan dan 
keterampilan pengelolaan ekowisata, (b) ekowisata model pemanfaatan jasa lingkungan untuk pelestarian lingkungan, (c) nilai ekonomi dan sosial ekowisata bagi masayarakat desa, (d) kekuatan kelompok dalam pengembangan ekowisata (e) struktur pengembangan ekowisata, (f) evaluasi dan monitoring dalam pengembangan ekowisata dan (g) pengelolaan ekowisata secara terpadu dan berkelanjutan. (2) Materi tata kelola potensi ekowisata sebegai sumber matapencaharian berkelanjutan, (3) Materi potensi kearifan masyarakat untuk mendukung pengembangan ekowisata, (4) Desain model promosi ekowisata alam di Desa Pijot,

\section{B. Pelaksanaan}

Pengembangan ekowisata di Desa Pijot berdasarkan solusi dari permasalahan seperti yang telah diuraikan di atas membutuh metode pelaksanaan yang relevan. Beberapa metode yang digunakan adalah:

1. Sosialisai, pada tahap ini Tim mensosialisaikan tema program pada pemerintah Desa, tokoh masyarakat dan stakehoulder lainnya. Metode yang digunakan adalah diskusi. Tujuan pada program sosialisai adalah untuk memperoleh pemahaman yang sama tentang pentingnya pengembangan ekowisata sebagai sumber matapencaharaian berkelanjutan masyarakat di Desa Pijot.Selain itu disampaikan luaran yang perlu dicapai dari tipa solusi permasalahan.

2. Metode Pelatiahan untuk pelatih (Training of Trainer), metode ini menggunakan modul yang dikembangkan sesuai dengan tiap solusi dari permaslahan seperti yang telah diuraikan di atas. Dalam setiap modul terdiri dari empat bagian yang terdiri dari: (a) langkah-langkah yaitu uraian yang menjelaskan langkah demi langkah yang dapat dilakukan oleh fasilitator dalam memfasilitasi kegiatan pelatihan pada tiap program, (b). bahan bacaan adalah materi bacaan yang dapat dijadikan referensi bagi fasilitator atau pelatih mengenai isi materi yang akan disampaikan dan (3) lembar kegiatan yang merupakan lembar aktivitas yang digunakan peserta dalam proses pembelajaran dan slide presentasi

3. Fokus Group Diskusi (FGD) adalah metode yang digunakan berdasarkan relevansi tiap solusi, hal ini sangat penting untuk memperoleh informasi mengenai beberapa pertanyaan tentang bagaiamana dan mengapa kita butuhkan ekowisata sebagai sumber matapencaharian yang berkelanjutan bagai masyarakat di Desa Pijot Induk.

4. Sosialisasi, metode ini digunakan untuk memberikan pemahaman secara komprehensif bagai tiap stakehouder sesuai dengan solusi dari tiap permasalahan pada pengembangan ekowisata di Desa Pijot.

5. Model contoh, metode ini akan didesaian dalam memilih kelompok kecil masyarakat atau lingkungan sosial pada level dusun berdasarkan kesepakan dari semua unsur pemerintah desa dan tokoh masyarakat yang lain untuk menerapakan solusi dari semua permasalahan dalam pengembangan ekowisata di Desa Pijot

\section{Hasil dan Pembahasan}

Program pengabdian pada masyarakat yang telah dilaksanakan di Desa Pijot secara keseluruhan dari yang direncanakan sudah berhasil. Indikatornya adalah: (1) kelembagaan yang sebelumnya belum ada setelah kegiatan pengabdian desa Pijot memiliki kelembagaan khusus untuk mengelola ekowisata yaitu Pokdarwis, (2) masyarakat sudah memiliki kesadaran akan pentingnya pengembangan ekowisata sebagai sumber matapencaharian masayarakat lokal yang berkelanjutan dan hal ini bisa dilihat dari partisivasi mereka dalam banyak kegiatan yang direncanakan oleh Tim dan mitra, seperti untuk menjaga kebersihan lingkungan dan rehabilitasi lahan mangrove melalui penanaman mangrove pada lokasi yang masih kosong, (3) regulasi, pemertintah desa telah memiliki memfasilitasi pembuatan regulasi ekowisata dengan melibatkan semua stakehoulder. Strategi menurut Ariani1 dan Nursan (2017) adalah suatu seni menggunakan kemampuan dan sumberdaya yang dimiliki suatu organisasi untuk mencapai sasarannya melalui hubungan yang efektif dengan lingkungan dalam kondisi saling menguntungkan. Tipe strategi meliputi (1) strategi organisasi, (2) strategi program, (3) strategi pendukung sumberdaya dan (4) strategi kelembagaan. Strategi pengembangan pariwisata menitikberatkan pada strategi pendukung sumberdaya dan strategi kelembagaan. Selanjutnya, Tim dan mitra melakukan dokumentasi dan diskripsi objeks wisata alam di Desa Pijot, diantaranya adalah: 
1) Pantai Batu Selayar (Gambar 2) adalah merupakan objek wisata baru yang akan dibuka di desa Pijot sehingga pantai ini memerlukan perhatian khusus baik dari pemerintah desa maupun masyarakat setempat. Pantai ini sudah memiliki keunikan dan keindahan tersendiri sehingga kami berupaya menjalankan beberapa program yang dapat membantu mempromosikan wisata pantai batu selayar tersebut. Program yang kami laksanakan tidak akan berjalan tanpa adanya bantuan dari masyarakat Pijot itu sendiri sehingga partisipasi dari masyarakat sangat diperlukan demi kelancaran dan keberlanjutan program. Untungnya masyarakat Pijot menyambut baik dan mendukung kegiatan-kegiatan yang kami lakukan yang terlihat dari partisipasi mereka dalam mengikuti beberapa kegiatan yang salah satunya adalah kegiatan membersihkan pantai batu selayar. Selain dapat dinikmati keindahannya, pantai juga merupakan tempat mencari nafkah bagi sebagian masyarakat terutama di desa Pijot karena sebagian besar masyarakat bekerja sebagai nelayan. Mereka biasanya ke pantai untuk mencari berbagai hasil laut seperti ikan, udang, kepiting, dan lain sebagainya. Hasil tangkapan tersebut nantinya akan dijual atau bisa juga untuk dikonsumsi sendiri. Mengingat banyaknya fungsi dan manfaat yang dimiliki oleh pantai, sudah seharusnya masyarakat menjaga keindahan dan kelesatarian pantai itu sendiri karena selain dapat menjadi ladang eknomi bagi masyarakat, pantai juga memiliki banyak kekayaan laut yang perlu untuk dijaga dan dilestarikan keberadaannya.

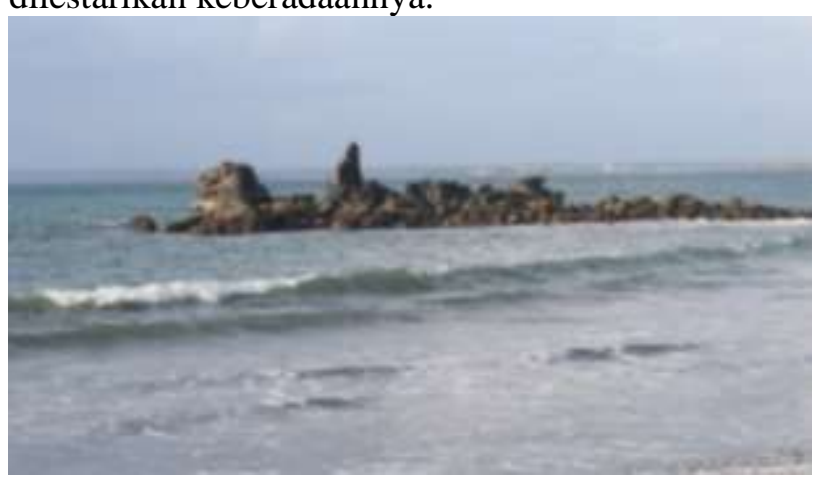

Gambar 2. Pantai Batu Selayar Desa Pijot

2) Wisata Mangrove (Gambar 3), Hutan Mangrove merupakan bagian ekosistem pesisir yang menyediakan sumber daya alam produktif, baik sebagai sumber pangan, media komunikasi maupun kawasan rekreasi atau pariwisata. Peranan hutan Mangrove dalam kehidupan ditunjukkan oleh fungsi mangrove terkait aspek sosio-ekologis, sosio-ekonomis dan sosio-kultural. Fungsi ekologis hutan mangrove yang paling menonjol adalah sebagai pelindung garis pantai dan kehidupan di belakangnya dari gempuran tsunami dan angin, mencegah terjadinya salinasi pada wilayah-wiayah di belakngnya dan sebagai habitat bagi biota

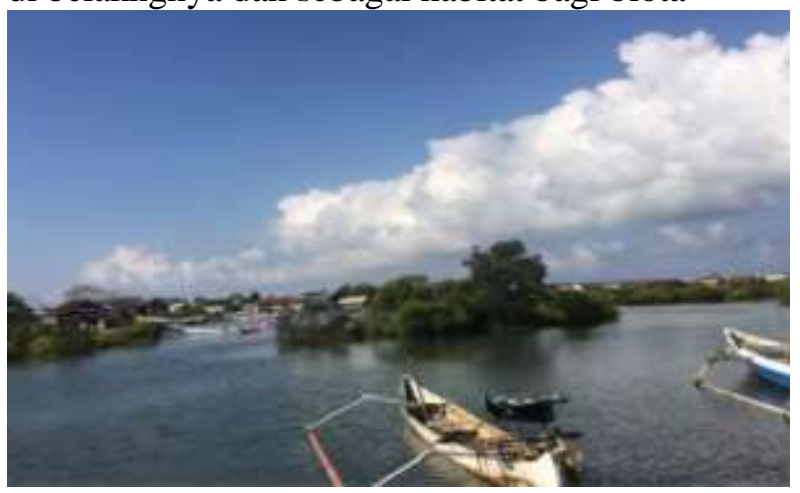

Gambar 3. Wisata kawasan Mangrove

Di Pijot sendiri tidak sulit untuk menemukan mangrove karena desa Pijot memiliki wilayah pantai yang cukup luas sehingga mangrove dapat dijumpai dengan mudah di beberapa tempat. Banyak masyarakat yang berkerja sebagai nelayan tinggal di daerah pesisir dan dengan disekitar pemukiman mereka dikelilingi oleh kawasan mangrove. Mangrove tersebut ditanam sendiri oleh masyarakat pesisir karena mereka sadar akan pentingnya keberadaan mangrove untuk mencegah air laut naik ke rumah mereka. Melihat fakta tersebut, kami tidak kesulitan untuk menemukan bibit mangrove di desa Pijot. Kami hanya perlu mencabut beberapa mangrove kecil untuk dijadikan bibit yang kemudian akan ditanam kembali di daerah pantai yang masih kekurangan tanaman mangrove. Pencabutan bibit ini tentu saja kami lakukan dengan izin dan persetujuan dari masyarakat setempat. Mereka bahkan ikut membantu selama proses pencabutan bibit dilakukan.

Setelah pencabutan bibit, kegiatan selanjutnya yang kami lakukan adalah penanaman pohon mangrove. Lokasi yang kami pilih sebagai tempat untuk menanam pohon mangrove adalah di sepanjang jalan menuju pantai Batu Selayar. Kami memilih pantai tersebut sebagai lokasi penanaman dikarenakan di pantai tersebut hanya terdapat beberapa pohon mangrove. Di sekitar pantai tersebut juga terdapat pemukiman warga sehingga dengan dilakukannya penanaman mangrove disana dapat mencegah air laut naik ke rumah warga. 
Selain itu pantai batu selayar juga menjadi objek wisata baru yang akan dibuka di desa Pijot sehingga penanaman mangrove pantai tersebut tidak hanya dapat mencegah terjadinya abrasi pantai tetapi juga dapat menambah keindahan pantai itu sendiri. Pantai yang indah tentu saja juga akan menarik wisatawan untuk berkunjung. Selain itu, mangrove sendiri dapat menjadi habitat bagi beberapa jenis hewan seperti kepiting bakau, ikan, udang, dan beberapa jenis hewan lainnya. Jadi mangrove tidak hanya bermanfaat bagi manusia tetapi juga bagi bagi beberapa jenis hewan. Aktivitas masyarakat dalam rehabilitasi lahan untuk mendukung ekowisata alam di Desa Pijot adalah melalui penanaman mangrove (Gambar 4 dan 5).
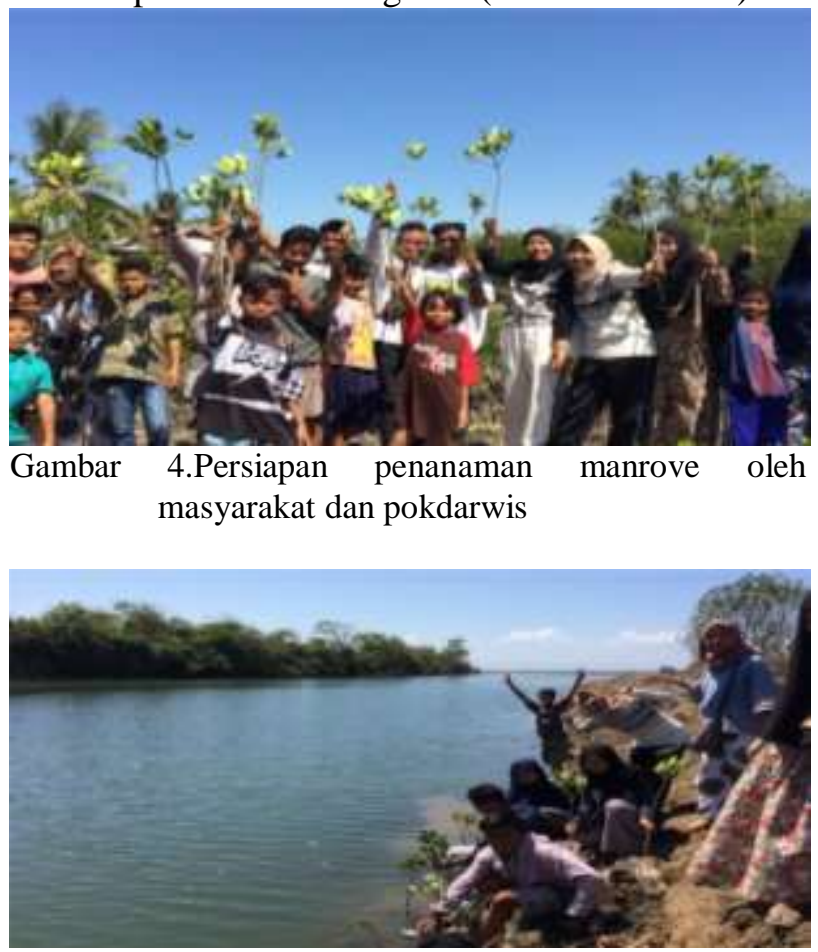

Gambar 5. Penanaman Bibit Mangrove di Pantai Batu

Selayar, oleh masyarakat dan pokdarwis

3) Wisata Kolam (Gambar 6 dan Gambar 7), Waterpark adalah adalah sebuah taman hiburan yang memiliki area/wahana permainan air seperti water slides,splash pads, spray grounds(water playgrounds) lazy rivers dan rekreasi lainnya seperti berenang dan mandi air, menurut kamus bahasa inggris waterpark adalah water,air,park;taman: taman public atau area yang digunakan untuk masyarakat. Selain memilki objek wisata pantai Desa Pijot juga memilki objek wisata yaitu kolam yang diberi nama kolam Tibu Gempur yang berada ,berlokasi di tengah sawah yang juga memiliki keunikan dari kolam lainnya.Namun,
Kolam ini Masih dalam tahap pembuatan yang belum mencapai $30 \%$ sehingga masih membutuhkan waktu yang lama untuk bisa dikunjungi dan dnikmati oleh masyarakat. Kolam Tibu Gempur saat ini masih dalam proses pembuatan yang beum mencapai $30 \%$ karena kalau diiihat dari kondisi dan prosesnya pembautannya baru masih tahap pembuatan desain dan masih belum dikerjakan dan hanya proses pengukuran tempat, Namun terakhir melihat kondisi kolam Tibu Gempur sekarang berlanjut ke tahap pembuatan lubang atau kawasan kolamnya. Setelah melakukan observasi dan wawancara dengan Kades Desa Pijot maka permasalahan yang muncul adalah bagaiaman pihak desa Mendesan kolam tersebut terutama Desai gapura yang ada di kolam tersebut dan bagaimana caranya untuk menpublikasikan kola tersebut sehingga kolam tersebut bisa dilihat dan diakses oleh masyarakat luar. Selain dalam hal pembuatan desain gapura, tidak jarang kami juga diminta untuk memberikan beberapa masukan lain seperti fasilitas yang perlu disediakan sehingga kami sering melakukan survey ke lokasi pembuatan kolam dan melakukan diskusi dengan kepala desa. Kami juga membantu mengambil gabar lokasi pembuatan kolam dari atas dengan menggunakan drone sehingga untuk memberikan gambaran lokasi secara keseluruhan dimana hal tersebut dapat membantu pihak desa dalam menentukan desain kolam yang ingin dibuat.
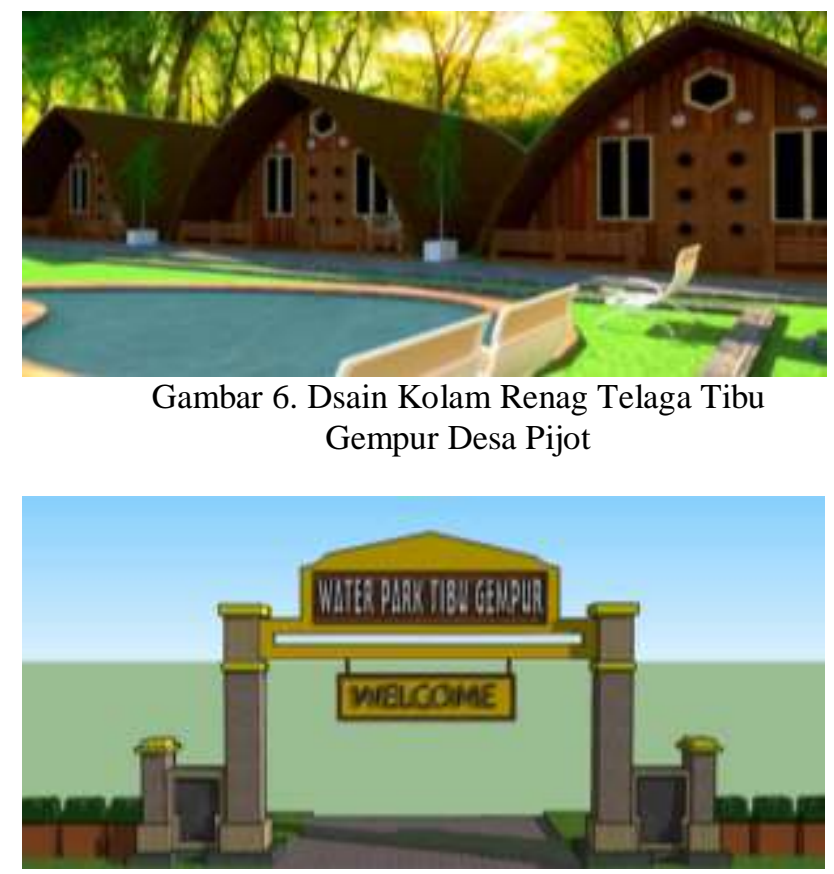

Gambar 7. Dsain Gapura Telaga Tibu Gempur Desa Pijot 
Pelaksanaan pengabdian pada masyarakat ini, dari hasil evaluasi ditemukan beberpa faktor pengahambat, diantaranya adalah:

1. Partisipasi, hal ini adalah kendala utama pada saat pertama menjelaskan program pengabdian pada masyarakat di Desa Pijot. Hal ini disbebakan karena masyarakat menilai bahwa program pengabdian pada masyarakat didentikan sebagai proyek, seperti yang banyak dilakukan oleh pihak yang pernah membawa program ke Desa Pijot. Namun demikian, setelah mereka diberikan pemahaman baru mulai muncul kesadaran bahwa program pengabdian adalah untuk membantu mereka dalam mereulasi potensi desa sebagai sumber matapencaharian.

2. Komuniskasi, hal ini adalah kendala yang dirasakan oleh tim pengabdian, namun demikian setelah pembentukan kelembagaan dan terbentuk mitra yaitu pokdarwis komunikasi semua program dapat dilakukan secara efektif oleh mitra. Waktu, selaian itu, waktu adalah kendala dalam pertemuan dengan masyarakat karena mereka adalah petani dan nelayan yang memiliki waktu yang berbeda, tetapi dengan fasilitasi oleg pakdarwis kendala waktu dapat diatasi pada setiap pertemuan tim dan masyarakat sasara.

Aspek konservasi adalah hal yang paling penting harus dipertimbangkan dalam kebijakan di tingkat lokal, terutama lingkungan laut sebagai objkes wisata seperti mangrove, lamun dan ekosistem lain (Syukur et al., 2018). Pada persepktif ini masyarakat belum memiliki kesadaran yang dibutuhkan untuk konservasi.

\section{Kesimpulan}

Pelaksanaan kegiatan pengabdian pada masyarakat tentang pengembangan ekowisata di Desa Pijot dapat dirumuskan beberapa kesimpulan adalah: Kelembagaan pengembangan ekowisata di Desa Pijot telah ada dalam struktur kelembagaan desa dan telah berperan secara aktif dalam mempromosikan destinasi wisata alam di Desa Pijot. Selain itu, Desa Pijot memiliki tiga destinasi alam unggulan yaitu wisata pantai, mangrove dan kolam permandian Kebun Telaga. Selanjutnya, masyarakat Desa Pijot telah memiliki pemahaman bahwa ekowisata adalah salah satu sumber matapencaharaian yang potensial bagi masyarakat lokal dan bisa mmenekan jumlah anak muda yang jadi pengangguaran.

\section{Ucapan Terimakasih}

Tim Pengabdian menyampaikan ucapan terimaksih pada Rektor Universitas Mataram yang telah memberikan dana melalui PNBP FKIP Unram tahun anggaran 2019.

\section{Daftar Pustaka}

Agil, Al. I., Syukur, A dan Zulkifli, L. 2017. Konservasi Mangrove melalui Pendekatan Intitusi Masyarakat Lokal untuk Pengembangan Ekowisata dan Sumber Belajar Biologi di Pantai Lombok Timur Selatan

Ariani, Z., \& Nursan, M. (2017). Strategi Pengembangan Desa Mantar sebagai Kawasan Desa Wisata di Kabupaten Sumbawa Barat. Jurnal Biologi Tropis, 17(2), 58-68.

Hartini, H., \& Lestarini, Y. (2019). Pemetaan Padang Lamun Sebagai Penunjang Ekowisata di Kabupaten Lombok Timur. Jurnal Biologi Tropis, 19(1), 1-7

Laporan KKN Revolusi Mental Universitas Mataram 2016.Indonesia Mandiri Mewujudkan Desa Pijot sebagai Sentra Garam Beryodium dan Desa Wisata Pantai

Laporan KKN Tematik Universitas Mataram 2017. Peningkatan Ekonomi Masyarakat Melalui Optimalisasi Potensi Objek Wisata Baru Berbasis Konservasi di Desa Pijot Induk Kecamatan Keruak Lombok Timur Monogarafi Desa Pijot, 2018

Putriningtias, A., Faisal, T. M., Komariyah, S., Bahri, S., \& Akbar, H. (2019). Keanekaragaman Jenis Kepiting di Ekosistem Hutan Mangrove Kuala Langsa, Kota Langsa, Aceh. Jurnal Biologi Tropis, 19(1), 101-107.

Syukur, A., Mahrus, Shachrudin Ar. 2018. The Perspective of Small Fisherman toward the Seagrass Conservation Values for the Sustainability of Friendly Environmental Fish Farming: a Case Study in Coastal Waters of East Lombok 